\title{
Oropharyngeal Leech Infestation and Therapeutic Options
}

\author{
Orofarengeal Sülük İnfestasyonu ve Tedavi Seçenekleri
}

\author{
Fatih OĞHAN'1 , Ali GÜVEY', Mahmut ÖZKiRiş², Erim GÜLCAN \\ 'Department of Otorhinolaryngology and Internal Medicine, Medical School, Dumlupınar University, Kütahya \\ ²Department of Otorhinolaryngoloy, Kayseri Tekden Research Hospital, Kayseri, Turkey
}

\begin{abstract}
This is a case report about a rare oropharyngeal foreign body causing oropharyngeal symptoms such as sore throat, dysphagia and hemoptysis. We reported a 7 year-old boy who had ingested a leech from a bottle which had been filled with water and it had attached to the palate within 4 days. The leech was identified as approximately $3 \mathrm{~cm}$ in length. Leech was removed under premedication by using monopolar cauterization. Although child infestation by a leech in the upper respiratory tract is very rare, it should be investigated when contaminated liquids are ingested. Electro cauterization should be borne in mind as a therapeutic option in the treatment of leech infestations in the upper respiratory tract under pre-medication in pediatric patients. (Turkiye Parazitol Derg 2010; 34: 200-2)
\end{abstract}

Key Words: Leech, oropharynx, treatment

Received: 24.04 .2010

Accepted: 28.09 .2010

\section{ÖZET}

Bu vakada hemoptizi, disfaji ve boğaz ağrısı gibi semptomlara yol açan bir orofarengeal yabancı cisim tartışılmıştır. Içi su ile dolu ve sülük bulunan şişeden su içen ve 4 gündür şikayetleri bulunan 7 yaşında erkek hastanın, yumuşak damağına yapışık halde bir kitle tespit edilmiştir. Kitle yaklaşık $3 \mathrm{~cm}$ uzunluğunda olup, sülük olarak tanımlanmıştır. Premedikasyon altında monopolar koter kullanılarak sülük alınmıştır. Üst solunum yollarında sülük infestasyonu nadir olmasına karşın, sülük ile kontamine su içen kişilerde görülebilmektedir. Çocuk hastalarda üst solunum yollarında sülük tespit edildiğinde, premedikasyon altında elektrokoterizasyonun bir tedavi seçeneği olabileceği unutulmamalıdır. (Turkiye Parazitol Derg 2010; 34: 200-2)

Anahtar Sözcükler: Sülük, orofarenks, tedavi

Geliş Tarihi: 24.04.2010 Kabul Tarihi: 28.09.2010

\section{INTRODUCTION}

Human infestation of a leech, especially in urban areas, is very rare. It usually occurs in individuals who swim in streams or drink infested water (1). After the contaminated water is drunk, the leech may adhere to anywhere along the upper aerodigestive tract. Possible areas are the nasal cavity, oropharynx and hypopharynx, larynx, trachea, and esophagus (2-4).

When adhere dto the mucous membrane, leeches ingest blood averaging $890 \%$ of their weight. For this reason, aquatic leeches may be dangerous, and also they can cause severe anemia which may require blood transfusion (2). Anemia and respiratory obstruction, especially in children, may endanger lives, even possibly causing fatalities. We have reported a child in an urban area who ingested a leech from a bottle that had been filled with water, whichattached to the palate within 4 days. The current literature is reviewed and the therapeutic options are discussed.

\section{CASE REPORT}

A 7 year-old boy presented at our clinic who had a 4 day history of oropharyngeal symptoms such as sore throat,

Address for Correspondence/Yazışma Adresi: Dr. Fatih Oğhan, Department of Otorhinolaryngology and Internal Medicine, Medical School, Dumlupınar University, Kütahya, Turkey Mobile: +90 5057267375 E-mail: fatihoghan@hotmail.com 
dysphagia and hemoptysis. A leech was ingested from a bottle that had been filled with water, but his parents were unaware of this. They suspected aspiration of something into the respiratory tract and they saw that the oropharynx was sub-totally obstructed by the purplish foreign body.

After examination, we saw blood clots on the soft palate and an adherent foreign body in that location. When other otolaryngeal examinations and the blood count and clotting test were normal, the foreign body was quickly removed after pre-medication via electro-cauterization. The leech was identified as approximately $3 \mathrm{~cm}$ in length (Fig. 1). No bleeding occurred in the extraction site.

\section{DISCUSSION}

Approximately 600 leech species have been identified to date, but only about 15 different types are used in medicine. Various anticoagulant agents are known to be injected by a leech. Theromyzon tessulatum, cytin (chymotrypsin inhibitor), tessulin (trypsin and chymotrypsin inhibitor), therin (trypsin inhibitor), theromin (thrombin inhibitor), and therostatin (factor Xa inhibitor) have been identified (5). The medical leech injects hirudin among a cocktail of many other anticoagulants.

One of many therapeutic applications of leeches results from this local injection of anticoagulants, especially in the field of reconstructive surgery, preventing hemostasis in flaps (6). It is still used in Europe and the United States by surgeons for these properties that make them useful when the venous tissue is compromised and the leech merits its name, Hirudo Medicinalis. Hirudotherapy is a treatment using medical leeches. Because of their saliva containing anticoagulant and a histamine-like vasodilator, they are useful for providing critical venous outflow for compromised tissue replants and transfers that might otherwise be unsalvageable (7). The existence of skin visceral connections with the definite organs is well known. Biologically active substances act on organs during the blood-sucking process of medicinal leeches through veins. It promotes the improvement of blood circulation in the

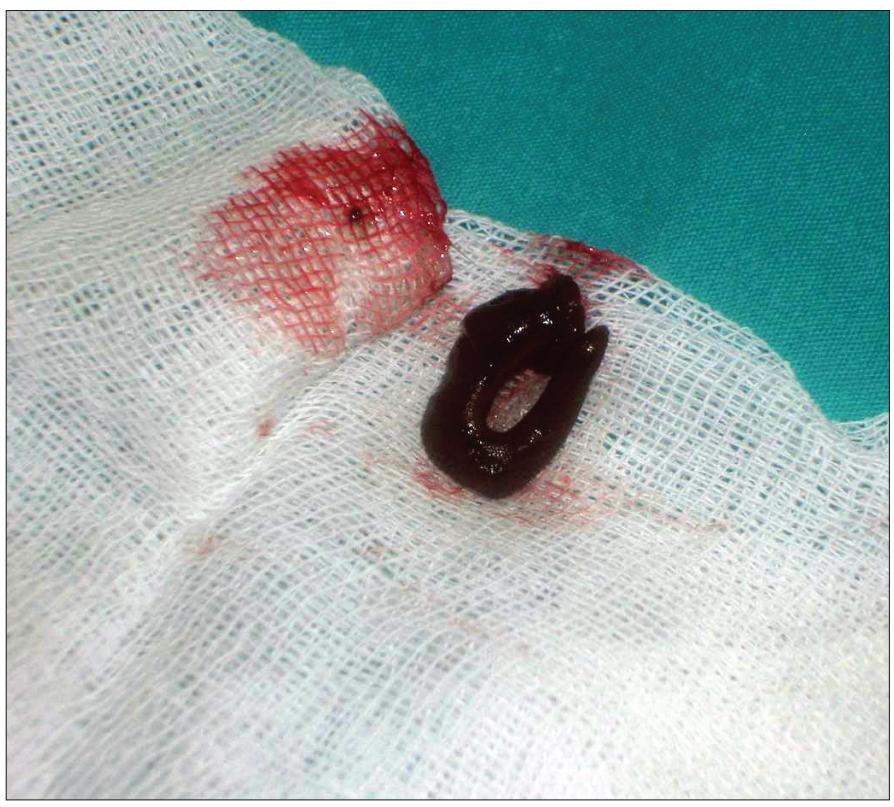

Figure 1. Leech obtained from the case organ, renders a thrombolytic, anti-inflammatory, immune stimulating action, increases nutrition of tissues, and strengthens tissues immunity. The removal of a leech in the upper aero-digestive tract should be performed with caution to prevent prolonged bleeding. It adheres firmly to the mucosa, with either insertion of a proboscis or a triple-jawed mouth.

When lodged in the oropharynx, the leech is able to simulate the symptoms of angio-edema. Signs of mechanical obstruction, including unilateral nasal obstruction, dysphagia, dysphonia, or dyspnea can progress in time, since the leech will increase its size during the period of feeding. In this case, the patient had dysphagia.

For many years, leeches have been used in modern medicine to encourage the blood flow to skin and muscle flaps, improving blood circulation and helping quiker healing in Turkey. Also, in our case, the patient's mother had had breast reconstructive surgery with a transverse rectus abdominis myocutaneous (TRAM) flap and leeches were used after surgery to improve its blood flow, and the child was infested by a leech from a bottle which has been filled with water without his parents' knowledge. Although oropharyngeal leech infestation is not common in urban areas, this case of oropharyngeal leech infestation had occurred in an urban environment because of the patient's mother's surgery in which leeches had been used. Also, Kuehnemund et al. (8) reported that human infestation of a leech, especially in urban areas, is very rare.

In therapy, removal of a leech requires special care and utmost gentleness because it attaches strongly with its suckers. This procedure can be performed under general or topical/local anesthesia. Different methods of detaching a leech from the mucosa other than mechanical have been proposed, such as injection of local anesthetics or superficial application of toxic agents (9). In Kuehnemund's (8) study, the leech was removed easily with forceps without complications. If it is in the nares or upper pharynx, it can be paralysed with cocaine and extracted directly (10). As an alternative to cocaine, as in the Bilgen et al. (3) case study, topical anesthetic agents, such as Lidocaine, are effective in paralyzing leeches. If it is in the larynx, hypopharynx or lower pharynx, direct laryngoscopy is needed under general anesthesia, both for diagnosis and removal of the leech (3). Also, our patient's leech was in the oropharynx so, following pre-medication, it was removed quickly via electro cauterization.

\section{CONCLUSION}

In developing countries, the possibility of Hirudinea should not be overlooked and leech infestations have to be considered in the differential diagnosis of severe anemia in children. Electro cauterization should be borne in mind as a therapeutic option in the treatment of leech infestations in the upper respiratory tract under pre-medication in pediatric patients.

\section{Declarations}

There was no source of funding for our research. There was no competing interest. Ethical approval was given from the committee and the number of this document was 2007/4798.

\section{Conflict of Interest}

No conflict of interest was declared by the authors. 


\section{REFERENCES}

1. Lent $\mathrm{CM}$, Fliegner $\mathrm{KH}$, Freedman E, Dickinson MH. Ingestive behaviour and physiology of the medicinal leech. J. Exp. Biol. 1998; 137: 513-27.

2. al-Hadrani A, Debry C, Faucon F, Fingerhut A. Hoarseness due to leech ingestion. J. Laryngol. Otol. 2000; 114: 145-6

3. Bilgen C, Karci B, Uluoz U. A nasopharyngeal mass: leech in the nasopharynx. Int. J. Pediatr. Otorhinolaryngol. 2002; 64: 73-6.

4. Garcia AD, Martin AM, De Luna Gijon CA. Leech in the epiglottis: an unusual discovery in our times. Am. J. Otolaryngol. 2002; 23: 91-2.

5. Salzet M. Anticoagulants and inhibitors of platelet aggregation derived from leeches. FEBS Lett. 2001; 492: 187-92.
6. Pilcher H. Medicinal leeches: stuck on you. Nature 2004; 432: 10-1.

7. Kraemer BA, Korber KE, Aquino TI, Engleman A. Use of leeches in plastic and reconstructive surgery: a review. J. Reconstruct. Microsurg. 1988; 40: 381-6.

8. Kuehnemund M, Bootz F. Rare living hypopharyngeal foreign body. Head Neck 2006; 28: 1046-8.

9. Uygur K, Yasan H, Yavuz L, Dogru H. Removal of a laryngeal leech: a safe and effective method. Am. J. Otolaryngol. 2003; 24: 338-43.

10. White GB. Leeches and leech infestation. In: G.C. Cook (Ed.). Manson's Tropical Diseases. 20th ed. Saunders, London, 1998; 1523-5. 